\title{
The spark of life: Electricity in the human body
}

\section{BOOK TITLE:}

The spark of life: Electricity in the human body

\section{BOOK COVER:}

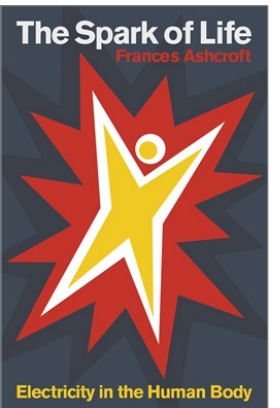

\section{AUTHOR:}

Frances Ashcroft

ISBN:

9781846143014

\section{PUBLISHER:}

Penguin Books, London, R304 (hardcover), R133.95 (eBook)

PUBLISHED:

2012

\section{REVIEW TITLE:}

The spark of life: Electricity in the human body

\section{REVIEWER:}

Timothy Kuiper

\section{EMAIL:}

timothykuiper@gmail.com

\section{AFFILIATION:}

Department of Zoology and Entomology, Rhodes University, Grahamstown, South Africa

\section{POSTAL ADDRESS:}

Department of Zoology and Entomology, Rhodes University, P0 Box 94, Grahamstown 6140, South Africa

\section{HOW TO CITE:}

Kuiper T. The spark of life: Electricity in the human body. S Afr J Sci. 2014;110(7/8), Art. \#a0071, 1 page. http://dx.doi. org/10.1590/sajs.2014/a0071
A captivating read, The Spark of Life presents an inclusive and magnetic account of electricity in the human body. With story-like accounts of the history of electrical discovery and its role players, lucid reviews of school biology, and absorbing descriptions of discoveries at the cutting edge of neuroscience, this book has something in it for everyone. Ashcroft's persuasiveness leaves the reader both convinced of and fascinated by the essential role of electrical signals in our cells - these are what make us truly alive.

The opening pages of the book introduce the reader to its star player: the ion channel. These proteins, found in the membranes of every cell on earth, are the focus of the author's research as a Professor in Physiology at the University of Oxford. In her own words:

From the lashing of the sperm's tail to sexual attraction, the beating of our hearts, the craving for yet another chocolate, and the feel of sun on your skin - everything is underpinned by ion channel activity.

Each chapter that follows includes reference to the fundamental role of ion channels in just about every aspect of our physiology.

A tribute to the scientists and engineers who were instrumental in the illumination of animal electricity, the finer details of how ion channels generate electric currents in our body, and the structure and function of nerve fibres form the book's foundation. Later chapters give specific attention to the workings of the synaptic gap, the 'ins and outs' of chemical neurotransmission at the neuromuscular junction, and the heart as a 'pump controlled by electricity'. The significance of ion channels is solidified by accounts of their function in photosynthesis, water regulation in our bodies, fertilisation and cell death and in underpinning various clinical conditions such as cystic fibrosis and diabetes. The later chapters form somewhat of a climax, exploring how ion channels in our sense organs dictate the way in which we see the world around us, and how sensory experience is transformed into electrical impulses that our brains can interpret. In the penultimate chapter, the discussion extends beyond the purely functional. Here the reader will discover how the wiring of the brain influences thoughts, consciousness, emotions and personalities. The book ends with a peek into the future - including prospects of creating artificial memory and controlling computers directly with our minds.

Both the expert in the field and the layperson will appreciate the way in which Ashcroft uses the unique angle of the ion channel to elegantly contextualise modern neuroscience in a manner that makes it truly come alive. How ion channels in our nerve cells create electrical impulses, why eating a puffer fish might kill you, what exactly happens during a heart attack, how taste is detected and deciphered, how prosthetic arms can be controlled by thought alone and how memories are generated and stored - this book is filled with a plethora of attention-grabbing facts.

Beyond the facts, the author also takes the opportunity to describe how neuroscience has shaped her philosophy. According to this philosophy, 'we are no more than the integrated electrical activity of our brain cells', and 'free will...is merely an illusion.... construct of the brain'. On a lighter note, Ashcroft makes wide and frequent use of humour. In one instance she describes how the beat of the Bee Gees hit 'Staying Alive' helps trainee doctors perfect the rhythm used in CPR, while 'Another One Bites The Dust' provides an equally perfect (but far less appropriate) training aide.

From the intricacies of the $\mathrm{K}_{\text {aTp }}$ channel to electroconvulsive therapy, Ashcroft demonstrates a unique ability to make complicated science both comprehensible and appealing. In so doing, she exemplifies the purpose of popular science literature: bridging the gap between scientific research and literature and the territory of cultural and political dialogue. Helpful diagrams and portraits depicting fascinating classic experiments make for a more enjoyable and easy-to-follow read. In the field of neuroscience, in which new information is constantly being unearthed, books like The Spark of Life are invaluable.

Overall, I found this book to be a wonderful read and it comes with my highest recommendation. Should you choose to read it, you are bound to expand your knowledge and have fun doing so. 